\title{
REVENUES AND EXPENDITURES OF PUBLIC BUDGETS IN THE CZECH REPUBLIC RELATED TO GAMBLING ${ }^{1}$
}

\author{
RADIM BOHÁC̆
}

\begin{abstract}
This contribution deals with revenues and expenditures of public budgets related to gambling in the Czech Republic. The main aim of this article is to evaluate revenues and expenditures of public budgets related to gambling and to confirm the hypothesis that these revenues are higher than these expenditures. In the paper are used methods of description, synthesis, and analysis. Revenues of public budgets from gambling are many times higher than the direct government expenditures associated with gambling. The hypothesis that these revenues are higher than these expenditures was confirmed. It is possible to reduce government revenues from gambling tax and, on the contrary, increase gambling-related expenditures.
\end{abstract}

\section{Keywords}

Gambling; revenues; expenditures; public budgets

JEL Classification: E62, H71, L83

\section{Introduction}

A new legal regulation of operating gambling has been effective in the Czech Republic since 1 January 2017. This regulation consists of three laws, i.e. the Act

1 This paper has been elaborated within the programme "PROGRES Q02 - Publicization of Law in the European and International Context" which is realized in 2018 at the Faculty of Law of the Charles University.

2 Associate Professor of Financial Law and Financial Science, Department of Financial Law and Financial Science, Faculty of Law, Charles University, Czech Republic. The Author specializes in tax law and budgetary law. He is the author or co-author of 3 books and more than 20 reviewed articles in prestigious journals. He is a member of Information and Organization Centre for the Research on the Public Finances and Tax Law in the Countries of Central and Eastern Europe. Orcid.org/0000-0003-4496-4699. Contact email: bohac@prf.cuni.cz. 
on Gambling (Act no. 186/2016, on Gambling). This regulation replaced former ineffective Act on Lotteries and Other Similar Games enacted in 1990.

The enactment of this regulation has important effects upon public budgets, i.e. revenues (esp. revenue from gambling tax) and expenditures (esp. expenditures for preventing the emergence of pathological gambling and tax administration costs).

The main aim of this article is to evaluate revenues and expenditures of public budgets related to gambling and to confirm the hypothesis that these revenues are higher than these expenditures. In the paper are used methods of description, synthesis, and analysis.

New gambling legislation has been adopted recently. Therefore, relevant literature is not yet available. No commentary of the Gambling Act has yet been made. However, there are already some commentaries of the Gambling Tax Act (Boháč, Krasulová, 2017 or Pelc, 2016). There are also some guides for municipalities related to gambling (Vacek, 2014). In 2006, the book Gambling Law was published, which generally deals with this legal sector, but of course, does not take into account the new legal regulation of gambling (Kramáŕ, Hušák, 2006).

The first part of this contribution defines the hazard and describes the gambling market in the Czech Republic. The second part of the contribution focuses on the gambling reform that took place in the Czech Republic in 2016 and 2017. The third part is focused on gambling reform in the Czech Republic. The main parts of the paper are the fourth and fifth part which relate to revenues and expenditures of public budgets associated with gambling.

\section{Gambling and Gambling Market}

With regard to the topic of the article, it is necessary first to mention basic information about the gambling and gambling market in the Czech Republic. Gambling or hazard is generally understood as a very risky behavior, the outcome of which is a matter of chance.

The basics of legal regulation of gambling are contained in private law, in the Civil Code. This Code regulates bet, game and lot as types of aleatory contracts. By bet, at least one party undertakes to make a win against the other if the incorrect claim of the party is unknown to the parties, or if the other party's allegation of the event is correct. The game and the lot are not explicitly defined; the provisions on betting apply accordingly. 
The basic rule applicable to bets, games and lots is the rule of non-enforceability of winnings by courts. However, this rule does not apply to bets, games and lots operated by the State or subject to official permission.

In the area of public law gambling is a strictly regulated area. The reason is that gambling has a number of negative social consequences. These negative social consequences are summarized, for example, in the annual report on gambling in the Czech Republic in 2016 (Mravčík, 2017). It can be mentioned pathological dependence, indebtedness of gamblers and their families, personal bankruptcy, playing of recipients of social benefits and committing crimes.

As already mentioned in 2016, new gambling legislation was adopted. The Gambling Act regulates eight types of gambling that can be operated on the basis of licensing or notification. Specifically, it is the lottery, odds bet, totalizator game, bingo, technical game, live game, raffle and small size tournament.

The most damaging for society is the technical game. Technical game means a game operated through a technical device directly handled by the bettor. Technical games include, without limitation, reel slot machines, electromechanical roulette, and electromechanical dice. Live odds betting (in running betting) are also very dangerous. Odds bet means a game in which a win is subject to guessing a betting event (particular a sports result or a public attention event). Live odds betting are an odds bet type where the bets are accepted while the betting event unfolds (Act no. 186/2016, on Gambling).

Players lost in gambling in the Czech Republic in the year 2016 total CZK 39.3 billion, which represents the aggregate gross income of gambling operators. The sum of bets and other deposits was CZK 196.4 billion and the sum of wins paid to players was CZK 157.1 billion. It is also possible to mention the share of individual games in the gambling market in 2016 according to the bets and other deposits assigned to individual games. Technical games have the biggest share of these bets and other deposits, the second one is odds bet (Mravčík, 2017).

It follows that the most serious gambling (technical games) have the largest share in the gambling market.

\section{Gambling Reform in the Czech Republic}

The gambling reform in the Czech Republic had two phases. The first phase took place on $1^{\text {st }}$ January 2016 . The essence of this phase was only the increase of rates of levy from lotteries and other similar games. Until 2016, the rate of levy from lotteries and other similar games for slot machines and other technical devices was 
adjusted to a proportional part $(20 \%$ of the amount by which the total of the bet amounts exceeds the total of the prizes won) and a fixed part (CZK 55 per day for each slot machine and devices, approx. CZK 20,000 per year). The levy rate for other lotteries and other similar games was $20 \%$ of the amount by which the total of the bet amounts exceeds the total of the prizes won.

From 2016, the rate of levy from lotteries and other similar games for slot machines and other technical devices was increased (proportional part to $28 \%$ and fixed the part to CZK 80). The rate of levy from lotteries and other similar games for other lotteries and other similar games was increased to $23 \%$. However, the increase of the rate of levy from lotteries and other similar games was not accompanied by any other measures that would counteract the negative consequences of gambling. This brought the second phase of the reform from $1^{\text {st }}$ January 2017. As already mentioned, the second phase of the reform was completed by enacting a new legal regulation of operating gambling. This regulation consists of three laws, i.e. the Act on Gambling (Act no. 186/2016), the Gambling Tax Act (no. 187/2016).

The aim of this regulation is particularly protecting gambling participants, preventing and eradicating socially pathological phenomena connected to with operating these games, effective collecting tax revenues, opening the Czech gambling market to operators from the European Union countries and regulation of operating online gambling.

The Act on Gambling (Act no. 186/2016) regulates games of chance and their types, conditions governing their operation, measures for responsible gambling and, the jurisdiction of administrative authorities over the gambling operation. It is a complex and modern legal act. Measures for responsible gambling are mandatory player registration, operator's obligation to offer a self-limiting measure to the player, etc. Technical games and live games can be operated only in a gambling room or casino (previously these games could be operated in other places, such as in pubs or petrol pumps). The gambling tax has replaced the lottery and other similar games levy. Gambling tax rates remained basically the same as rates of the lottery and other similar games levy.

\section{Gambling Revenues of Public Budgets}

The gambling revenues of public budgets in the Czech Republic can be divided into two main groups. The first group are revenues from operators; the second group is revenues from players. The revenues of public budgets from players are very small. The reason is that most of the players' wins are exempt from individual income tax. Winnings of players are exempt of individual income tax, if they are from gambling 
which is licensed under the Gambling Act in the Czech Republic, from gambling which must be notified under this Act or from gambling which runs under the laws of similar gambling laws in the States of European Union or the States forming the European Economic Area. It follows that only wins from operators from third countries and from illegal operators are taxed.

Revenues of public budgets from operators can be divided into three groups. The first group are revenues of corporate income tax, the second group are revenues of administrative charges and the third group are revenues of gambling tax.

Gambling operators according to the Gambling Act may be only the Czech Republic represented by its organizational units or corporation. The corporation must fulfill a lot of conditions, e. g. a registered office in the Czech Republic; in another EU Member State; or in a state that is a party to the Agreement on the European Economic Area, a transparent and unobjectionable origin of its resources etc. (Act no. 186/2016, on Gambling, Sec. 6). Corporations and organizational units of the state are subjects (taxpayers) of corporate income tax in the Czech Republic. The gambling incomes are objects of this tax. If these corporations or units are operating gambling they must pay this tax. The tax base is determined as the difference between gambling revenues and gambling expenditures and the tax rate is $19 \%$ of the tax base.

The amount of the tax base of gambling operators can only be estimated. In 2013, according to the automated tax information system, gambling operators reported a corporation tax of CZK 653 million (Explanatory report to Gambling Tax Act). The difference between bets and wins was in 2013 CZK 29.3 billion and in 2016 CZK 39.3 billion, so the revenue should be higher. But, on the other hand, the gambling tax is an expense and its rates have been increased, so the revenue should be lower. It can be deduced that the corporate income tax revenue from gambling operators is about CZK 600-800 million per year.

Revenues from administrative charges paid by gambling operators are very small, rather symbolic. An administrative charge of CZK 5,000 is set for acceptance of the application for a basic license to operate gambling and of CZK 3,000 for acceptance of the application for a change of this license. These administrative charges are revenues of the state budget. An administrative charge of CZK 4,000 is set for acceptance of the application for gambling premises location license and of CZK 2,500 for acceptance of the application for a change of this license. These administrative charges are revenues of municipality budgets.

The highest revenue flows into public budgets from gambling tax, until 2017 from a levy on lotteries and other similar games. Until the increasing of levy on lotteries and other similar games rates from 2016 the total annual revenue of this levy was 
CZK 8,15 billion in 2013, CZK 7,98 billion in 2014 and CZK 8,08 billion in 2015. About $75 \%$ of this revenue was from technical games (CZK 6,08 billion in 2013, CZK 6,26 billion in 2014 and CZK 6,13 billion in 2015) and the remainder of other games (CZK 2,07 billion in 2013, CZK 1,72 billion in 2014 and CZK 1,94 billion in 2015). It is clear that the highest revenue came from technical games.

As noted above, from 2016 there has been an increase of lottery and other similar games rates. The total annual revenue of this levy was in 2016 CZK 10,49 billion. It means, that this increase brought more than 2,4 billion CZK per year for public budgets (state budget and municipality budgets). However, the revenue from technical games and other games remained approximately the same. The revenue from technical games was CZK 8,04 billion and the revenue from other games was CZK 2,45 billion.

Similar revenue as in 2016 should also be achieved in 2017. In 2018, however, a decline may be expected, as regulatory measures of the Gaming Act should be fully reflected. In particular, a reduction in the number of technical devices to operate a technical game can be expected. This should mean a decrease in the tax revenue from technical games. On the other hand, this loss of revenue from technical games can be partly compensated by an increase in revenue from other games, especially internet games.

Now I will deal with dividing the revenue of gambling text, (resp. levy on lotteries and other similar games) between individual public budgets. Municipal budgets received CZK 5.5 billion in 2013, 2014 and 2015 and CZK 6.1 billion in 2016 and state budget received CZK 2.6 billion in 2013, 2014 and 2015 and CZK 4.4 billion in 2016. The largest portion of revenue flowing to municipal budgets is shared between municipalities that have gambling rooms and casinos in their territory.

\section{Expenditures of Public Budgets associated with Gambling}

Expenditures associated with gambling are spent from the state budget and from municipalities and regions budgets.

Expenditures from municipalities and regions budgets are not quantified and it is very difficult to estimate them. There are 14 regions and more than 6200 municipalities in the Czech Republic and each region or municipality can spend some expenditures related to gambling. Expenditure on eliminating the negative phenomena associated with gambling will be spent by those municipalities which have gambling rooms or casinos in their territory and which are recipients of gambling tax revenue. 
There are special programs focusing on prevention against negative phenomena associated with gambling at the state budget level. These are programs of Government Council for Drug Policy Coordination. Expenditure on drug policy does not usually distinguish between different areas of drug policy such as alcohol, tobacco, illicit drugs and gambling (Mravčík et al.: 2017). But programs of Government Council for Drug Policy Coordination do so. Government Council for Drug Policy Coordination provides grants for prevention and treatment of problem gambling. The Council from its budget in the year 2016 supported 50 projects associated with gambling at total amount CZK 24.5 million. But to 2013 activities against consequences of gambling were not supported. In 2013-2015, Council submitted projects in the field of prevention and treatment of problem gambling of CZK 3-5 mil. per year (Mravčík et al.: 2017).

As can be seen, the direct spending on negative phenomena associated with gambling is not very large. However, it must be stressed once again that this is not all expenditures, but only those that can be quantified. Actual expenditures are higher. However, it can be estimated that there will be a maximum of hundreds of millions of Czech crowns.

Regarding gambling-related expenditures, it must be mentioned social costs for gambling. There are several studies that try to quantify these costs. But their results are quite different. The Psychiatric Centre in Prague study estimates these costs in 2012 at CZK 14.2-16.1 billion per year. However, about $75 \%$ of this amount is represented by intangible costs, especially emotional detriment and the suffering of players and their relatives (Winkler et al.: 2014).

The Centre for Economic and Market Analysis carried out a revision of the Psychiatric Centre in Prague study and arrived at its own estimate of social costs for the year 2012 at the level of CZK 5.3-5.7 billion (Schwarz et al.: 2015). Unlike the first study, this study does not include intangible costs.

\section{Conclusions}

The main aim of this article was to evaluate revenues and expenditures of public budgets related to gambling and to confirm the hypothesis that these revenues are higher than these expenditures.

I described gambling and gambling market in the Czech Republic first. The technical games have the largest share in the gambling market.

Then I focused on gambling reform in the Czech Republic. It is necessary, from a government's point of view, to seek a level of regulation that is optimal in terms 
of revenues and expenditures of public budgets, on the one hand, and which will lead to the protection of players and the fight against socially harmful phenomena associated with gambling on the other hand. Excessive regulation can lead to a decline in government revenue and a rise in the illegal operation of gambling. Conversely, little regulation can have same consequences. Finding a balance between these goals is therefore very difficult and there is a question whether the Czech legislator has succeeded in this to confirm the hypothesis that these revenues are higher than these expenditures.

In terms of public budgets revenues from gambling, the highest revenue flows into public budgets from gambling tax. The total annual revenue of lottery and other similar games levy was in 2016 CZK 10,49 billion. Similar revenue as in 2016 should also be achieved in 2017 from gambling tax.

In terms of public budgets expenditures associated with gambling expenditures from municipalities and regions budgets are not quantified and it is very difficult to estimate them. Expenditures of the state budget on drug policy do not usually distinguish between different areas of drug policy such as alcohol, tobacco, illicit drugs, and gambling. The exemption concerns the programs of Government Council for Drug Policy Coordination. The Council from its budget in the year 2016 supported 50 projects associated with gambling at total amount CZK 24.5 million.

It is obvious that public revenues from gambling are many times higher than the government expenditures associated with gambling. The hypothesis that these revenues are higher than these expenditures was confirmed. I think it is possible to reduce government revenues from gambling tax and, on the contrary, increase gambling-related expenditures.

\section{References}

Boháč, R., Krasulová, H.: Zákon o dani z hazardních her: komentář (Gambling Tax Act: commentary), Praha: Wolters Kluwer, 2017.

Důvodová zpráva k zákonu o dani z hazardních her (Explanatory report to Gambling Tax Act), Praha: Poslanecká sněmovna Parlamentu (Chamber of Deputies of Parliament), 2016. www.psp.cz.

Kramář, K., Hušák, A.: Herní právo (Gambling Law), Pilsner: Čeněk, 2006.

Mravčík, V. et al.: Výroční zpráva o hazardním hraní v České republice v roce 2016 (Annual Report on Gambling in the Czech Republic in 2016), Praha: Úřad vlády České Republiky, 2017.

Pelc, V.: Daň z hazardních her s komentářem (Gambling Tax Act: Comments), Olomouc: Anag, 2016. 
Schwarz, J. et al.: Regulace hazardu v ČR - východiska, podoba a dopady změn v legislativě (Regulation of Gambling in the Czech Republic - the Basis, the Form and Impact of Changes in Legislation), Praha: CETA, 2015.

Vacek, J.: Identifikace a řešení rizik spojených s hraním hazardních her: příručka pro obce a jejich zastupitele (Identifying and addressing the risks associated with gambling: a guide for municipalities and their representatives), Prague: Úřad vlády České Republiky, 2014.

Winkler, P. et al.: Problémové hráčství: Společenské náklady na hazardní hraní v České republice (Problem Gambling: The Social Costs of Gambling in the Czech Republic), Praha: Psychiatrické centrum Praha, 2014.

CZ: Act no. 186/2016, on Gambling, as amended.

CZ: Act no. 187/2016, on Gambling Tax, as amended.

CZ: Act no. 188/2016, which amends certain laws in connection with the adoption of the Gambling Act and the Gambling Tax Act. 